\title{
Avian population trends based on 27 years of data from California oak woodlands
}

\author{
Kathryn L. Purcell ${ }^{1,{ }^{*}}$ and Sylvia R. Mori ${ }^{2}$
}

\begin{abstract}
With 27 years of data (1986-2012), we examined long-term patterns of variation in abundance and population trends for 35 species of oak woodland birds. Following a standardized protocol, from three to eight observers counted birds annually at 210 count stations at the San Joaquin Experimental Range, Madera County, California. We used both linear regression and nonparametric regression (spline-smoothing the year effect) to evaluate population trends. The abundance of most species varied greatly over the study period, emphasizing the importance of long-term monitoring. Overall, 12 species increased: the California Quail (Callipepla californica), Anna's Hummingbird (Calypte anna), Red-tailed Hawk (Buteo jamaicensis), Acorn Woodpecker (Melanerpes formicivorus), Nuttall's Woodpecker (Picoides nuttallii), American Kestrel (Falco sparverius), Common Raven (Corvus corax), Violet-green Swallow (Tachycineta thalassina), White-breasted Nuthatch (Sitta carolinensis), Bewick's Wren (Thryomanes bewickii), European Starling (Sturnus vulgaris), and House Finch (Haemorhous mexicanus). Five species decreased: the California Scrub-Jay (Aphelocoma californica), Blue-gray Gnatcatcher (Polioptila caerulea), Western Bluebird (Sialia mexicana), Western Meadowlark (Sturnella neglecta), and Bullock's Oriole (Icterus bullockii). Of these, the Blue-gray Gnatcatcher, Western Meadowlark, and Bullock's Oriole present cause for concern. We recommend further research to elucidate the causes for the declines of these three species. We also recommend continued monitoring of the California Scrub-Jay and Western Bluebird to verify recovery to previous levels of abundance. Our results emphasize the need for long-term monitoring of avian populations, which will provide insights into population dynamics and may reveal negative trends that may require conservation action.
\end{abstract}

Keywords: Blue-gray Gnatcatcher, Bullock's Oriole, long-term monitoring, population decline, San Joaquin Experimental Range, smoothed trend curves, West Nile virus, Western Meadowlark

$\mathrm{P}$ opulation trends and information on whether species are increasing or decreasing in abundance are of central importance in species conservation and management (Dunn 2002). Declines of songbirds that migrate to the neotropics have been the subject of considerable interest for decades, especially in eastern North America (Terborgh 1989, Robbins et al. 1989, 1993). In western North America, concerns have centered primarily on declines in grassland and shrubland species (DeSante and George 1994). A recent review of long-term trend data suggests that bird populations are declining across several key North American habitats (NABCI 2014). These include arid lands, whose birds are experiencing the steepest population declines, and grasslands, where populations appear to be stabilizing at low levels following decades of decline. Concerns remain for neotropical migrants, as well as for species characteristic of rural landscapes.

To determine whether populations are increasing, decreasing, or stable, we collect data on abundance. Measures of annual abundance reflect the survival and productivity of animals as responses to changes in food availability, predation rates, habitat loss and degradation, weather conditions, and longer-term climate cycles (Holmes and Sherry 1988, DeSante and George 1994, Ballard et al. 2003). Regardless of the cause, knowledge of population trends is useful in identifying species that merit conservation interest and in prioritizing conservation actions (Askins et al.1990, Siriwardena et al. 1998, Joseph et al. 2006, Marsh and Trenham 2008).

Full citation: Purcell, K. L., and Mori, S. R. 2018. Avian population trends based on 27 years of data from California oak woodlands, in Trends and traditions: Avifaunal change in western North America (W. D. Shuford, R. E. Gill Jr., and C. M. Handel, eds.), pp. 198-214. Studies of Western Birds 3. Western Field Ornithologists, Camarillo, CA; doi 10.21199/SWB3.11.

${ }^{1}$ USDA Forest Service, Pacific Southwest Research Station, 2081 E. Sierra Avenue, Fresno, California 93710, ${ }^{2}$ USDA Forest Service, Pacific Southwest Research Station, 800 Buchanan Street, Albany, California 94710; *corresponding author: kpurcell@fs.fed.us 
Long-term datasets are necessary to detect even fairly large changes in the abundance of wildlife species (Purcell et al. 2005). Long-term studies, combined with carefully documented and archived data sets, can reveal species with declining populations and help us understand the loss of biodiversity at local and regional scales.

Since 1986 we have recorded data on avian abundance at the San Joaquin Experimental Range (SJER) and have applied a rigorous, standardized study design that helps control for sources of variability in count data. Using this dataset, we here examine long-term patterns and population trends for 35 bird species from 1986 through 2012. We identify species that show decreasing and increasing trends over the 27 years of the study and, on the basis of these trends, highlight species that merit conservation attention. We also indicate research needs.

\section{METHODS}

\section{STUDY AREA}

SJER is located in Madera County, California, within the western foothills of the Sierra Nevada (Figure 1). It occupies 1875 ha in blue oak-foothill pine woodland and ranges in elevation from 215 to $520 \mathrm{~m}$. Vegetation consists of a sparse woodland overstory of blue oak (Quercus douglasii), interior live oak (Q. wislizenii), and foothill pine (Pinus sabiniana), with an understory of scattered shrubs including wedgeleaf ceanothus (Ceanothus cuneatus), chaparral whitethorn (C. leucodermis), Mariposa manzanita (Arctostaphylos viscida ssp. mariposa), holly-leaf redberry (Rhamnus ilicifolia), and coffeeberry ( $R$. tomentella ssp. cuspidata). In some areas the overstory is primarily blue oak and the understory is fairly open. Soft chess (Bromus hordeaceus), ripgut brome (B. diandrus), Mediterranean barley (Hordeum geniculatum), wild oat (Avena barbata), annual blue grass (Poa annua), broadleaf filaree (Erodium botrys), popcorn flower, (Plagiobothrys nothofulvus), and common fiddleneck (Amsinckia menziesii var. intermedia) dominate the understory. SJER has been moderately grazed by cattle since about 1900 , except for a 29-ha Research Natural Area, which has been ungrazed since 1934 and has an accordingly dense shrub layer. The site's climate is Mediterranean, with cool, wet winters and hot, dry summers. Most precipitation falls as rain during the winter.

\section{BIRD DATA}

We assessed bird abundance on the basis of point counts from 1986 through 2012. The sampling array consisted of 210 count stations, with 30 stations distributed along each of seven lines established throughout SJER (Figure 1). Stations were at least $200 \mathrm{~m}$ apart, whether along the same line or on different lines. Although this spacing is closer than ideal for independent samples, it was adequate for our purposes, as our intent was to obtain only an index of relative abundance for comparison across years. Stations were clearly identified by yellow tags wired to trees, shrubs, fences, or occasionally to steel fence posts, providing consistency in location over the years. Red tags and flagging placed between stations helped guide observers from point to point along the lines. More recently, GPS units were used for navigation among points.

The counts' protocol was highly standardized to help control for variability due to factors such as time of year, time of day, conditions related to a particular day, and multiple observers. Counts extended from the last week of March to the end of April, being timed to coincide with the period of peak singing for most species that breed at SJER. Counts were evenly spaced within this period, with one or two counts done per week, except in 1986 and 1987 when observers counted each line twice (but still within the given sampling period). Variability among observers is generally considered the largest source of variability in bird counts, so we employed several tactics to help reduce this source of error (Verner and Milne 1989). Observers were carefully selected to be proficient at bird identification, especially by vocalizations. Observers underwent an initial oneto two-week training to sharpen their skills and familiarize them with the details of the protocol. The same observers were used for as many years as possible, with two observers counting birds in each of 3, 5, 6, and 8 years, and two completing counts in 15 and 18 years of the study.

Each year, from three to eight observers completed 5-minute point counts with unlimited distance at all stations. Observers were assigned to lines of stations randomly, and each observer sampled all lines on seven different mornings, completing one count at each of the 210 stations. Consequently, each point was counted each year as many times as the number of observers in that year, except in years when observers counted each line twice. The average number of times each station was counted was 4.8 per year, with a total of 129 counts at each station over the 27 years of the study. Stations were surveyed in the same sequence each time a line was sampled, further standardizing results. Counting at the first station 


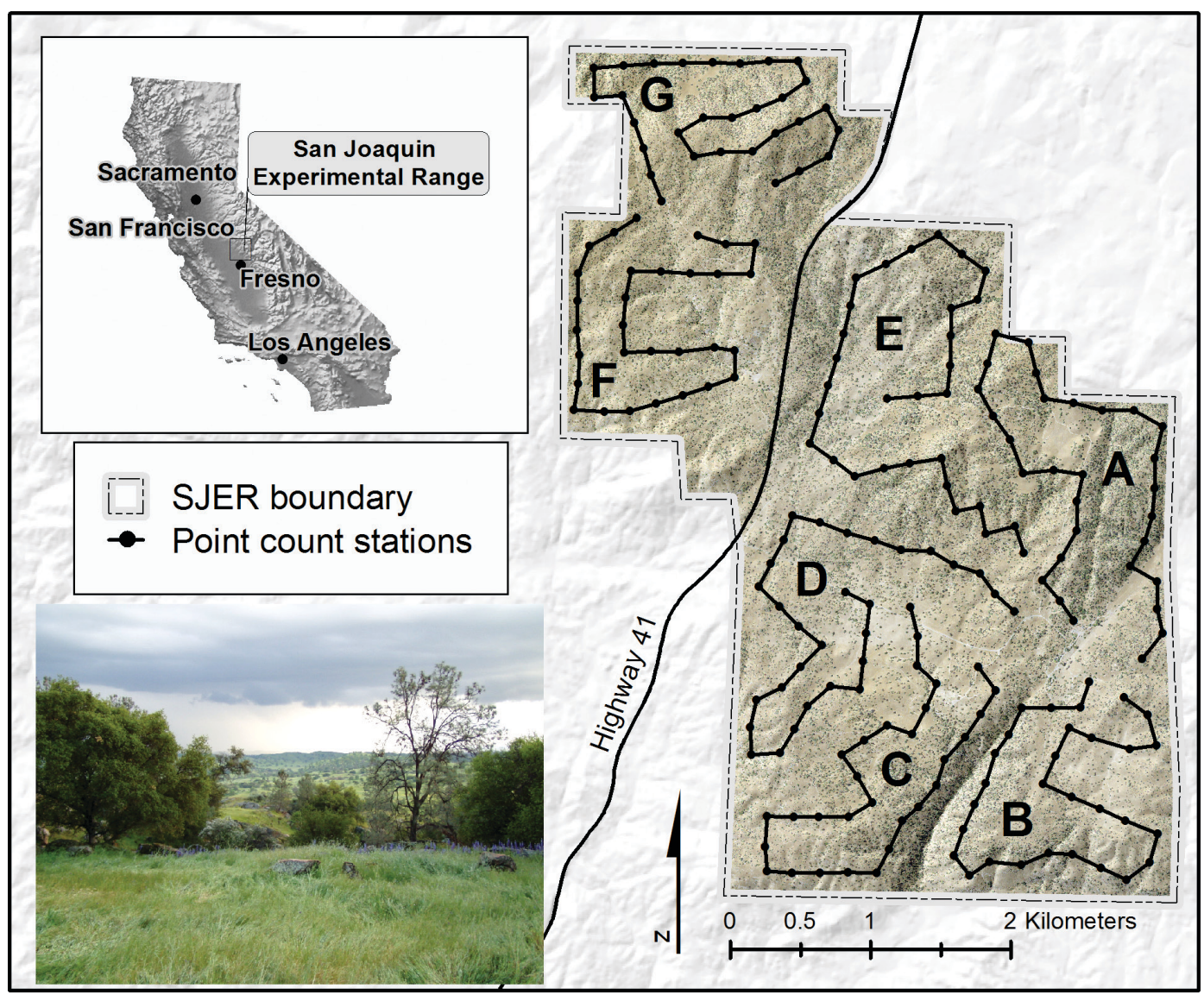

FIGURE 1. Location of the San Joaquin Experimental Range, Madera County, California, and array of 210 count stations arranged along seven lines $(\mathrm{A}-\mathrm{G})$ with 30 stations per line.

on a line began at 10 minutes after official sunrise. By adherence to this schedule, all 30 stations on a line were sampled within 5 hours. All observers counted on the same day to help control for date and factors related to weather conditions. Counts were not conducted on rainy days or when wind velocity exceeded $32 \mathrm{~km} / \mathrm{hr}$ (Beaufort scale 5).

\section{STATISTICAL ANALYSIS}

We initially considered for analysis those species with at least five detections in each of the 27 years of the study. Although 41 species met this criterion, in some cases it proved to be too lenient for adequate analysis of population trends. We dropped six species that met the criterion because (1) their abundance was too variable across years to model well (Northern Flicker Colaptes auratus, and Black-throated Gray Warbler Setophaga nigrescens), (2) there was high variability combined with low overall abundance across years (Cassin's Vireo Vireo cassinii, American
Robin Turdus migratorius, and Wilson's Warbler Cardellina pusilla), or (3) they were not counted accurately (Golden-crowned Sparrow Zonotrichia atricapilla). Scientific names of all other species treated in this paper appear in Table 1.

We analyzed population trends by means of a linear regression model, with bird abundance (mean count) as the dependent variable and year as the independent variable. Mean count was calculated as the average count over all observers at each count station each year. Trend was estimated by the slope of the regression line. The general form of the model was

\section{Mean count $=a+b \times$ year + route + residual error,}

where $a$ is the intercept and $b$ the slope measuring the yearly trend. Route (Figure 1, lines A-G), assumed to be a fixed class effect, was added to account for the location effect. The residual error is assumed to be a normally distributed random 
TABLE 1. The breeding and migratory status, the average number of bird detections per route recorded from 19862012, and the trend analysis from both linear and smoothed-curve regressions for 35 bird species at the San Joaquin Experimental Range. $P$-values for the smoothed-curve regression were all $<0.0001$; trends were determined by visual inspection of the graphs with respect to the null line. Trends are designated as increasing $(+)$, decreasing $(-)$, or no change (NC).

\begin{tabular}{|c|c|c|c|c|c|}
\hline \multirow[b]{2}{*}{ Species } & \multirow[b]{2}{*}{ Status ${ }^{a}$} & \multirow{2}{*}{$\begin{array}{l}\text { Mean number } \\
\text { of detections per } \\
\text { route }(\mathrm{SE})\end{array}$} & \multicolumn{2}{|c|}{ Linear regression } & \multirow{2}{*}{$\begin{array}{c}\begin{array}{c}\text { Smoothed-curve } \\
\text { regression }\end{array} \\
\text { Trend }\end{array}$} \\
\hline & & & Slope $p$-value & Trend & \\
\hline California Quail Callipepla californica & $\mathrm{RB}$ & $43.6(3.3)$ & $<0.001$ & + & + \\
\hline Mourning Dove Zenaida macroura & $\mathrm{RB}$ & $30.6(1.6)$ & 0.060 & NC & $\mathrm{NC}$ \\
\hline Anna's Hummingbird Calypte anna & $\mathrm{RB}$ & $5.9(0.6)$ & $<0.001$ & + & + \\
\hline Turkey Vulture Cathartes aura & $\mathrm{RB}$ & $11.2(2.4)$ & 0.464 & $\mathrm{NC}$ & $\mathrm{NC}$ \\
\hline Red-tailed Hawk Buteo jamaicensis & $\mathrm{RB}$ & $11.6(1.1)$ & $<0.001$ & + & + \\
\hline Acorn Woodpecker Melanerpes formicivorus & $\mathrm{RB}$ & $96.9(3.8)$ & $<0.001$ & + & + \\
\hline Nuttall's Woodpecker Picoides nuttallii & $\mathrm{RB}$ & $7.9(0.4)$ & $<0.001$ & + & + \\
\hline American Kestrel Falco sparverius & $\mathrm{RB}$ & $1.5(0.3)$ & $<0.001$ & + & + \\
\hline Ash-throated Flycatcher Myiarchus cinerascens & $\mathrm{MB}$ & $25.2(0.5)$ & 0.765 & $\mathrm{NC}$ & $\mathrm{NC}$ \\
\hline Western Kingbird Tyrannus verticalis & $\mathrm{MB}$ & $10.2(2.3)$ & $<0.001$ & + & NC \\
\hline Hutton's Vireo Vireo huttoni & $\mathrm{RB}$ & $1.3(0.4)$ & $<0.001$ & + & $\mathrm{NC}$ \\
\hline California Scrub-Jay Aphelocoma californica & $\mathrm{RB}$ & $31.6(1.0)$ & $<0.001$ & - & - \\
\hline Common Raven Corvus corax & $\mathrm{RB}$ & $19.3(1.7)$ & $<0.001$ & + & + \\
\hline Violet-green Swallow Tachycineta thalassina & $\mathrm{MB}$ & $29.6(3.1)$ & $<0.001$ & + & + \\
\hline Oak Titmouse Baeolophus inornatus & $\mathrm{RB}$ & $58.6(2.3)$ & $<0.001$ & - & $\mathrm{NC}$ \\
\hline Bushtit Psaltriparus minimus & $\mathrm{RB}$ & $13.6(0.8)$ & 0.962 & $\mathrm{NC}$ & $\mathrm{NC}$ \\
\hline White-breasted Nuthatch Sitta carolinensis & $\mathrm{RB}$ & $24.6(1.6)$ & $<0.001$ & + & + \\
\hline Canyon Wren Salpinctes obsoletus & $\mathrm{RB}$ & $2.3(0.9)$ & $<0.001$ & - & $\mathrm{NC}$ \\
\hline House Wren Troglodytes aedon & $\mathrm{MB}$ & $11.8(2.3)$ & 0.128 & $\mathrm{NC}$ & $\mathrm{NC}$ \\
\hline Bewick's Wren Thryomanes bewickii & $\mathrm{RB}$ & $15.7(2.5)$ & $<0.001$ & + & + \\
\hline Blue-gray Gnatcatcher Polioptila caerulea & $\mathrm{MB}$ & $1.4(0.2)$ & 0.003 & - & - \\
\hline Ruby-crowned Kinglet Regulus calendula & WR & $9.0(1.1)$ & 0.974 & $\mathrm{NC}$ & $\mathrm{NC}$ \\
\hline Western Bluebird Sialia mexicana & $\mathrm{RB}$ & $8.6(1.5)$ & $<0.001$ & - & - \\
\hline European Starling Sturnus vulgaris & $\mathrm{RB}$ & $30.7(4.8)$ & 0.016 & + & + \\
\hline House Finch Haemorhous mexicanus & $\mathrm{RB}$ & $22.7(1.1)$ & $<0.001$ & + & + \\
\hline Lesser Goldfinch Spinus psaltria & $\mathrm{RB}$ & $19.8(1.4)$ & 0.001 & - & $\mathrm{NC}$ \\
\hline Orange-crowned Warbler Oreothlypis celata & M & $4.0(0.6)$ & 0.005 & + & $\mathrm{NC}$ \\
\hline Yellow-rumped Warbler Setophaga coronata & M & $42.0(2.2)$ & $<0.001$ & + & $\mathrm{NC}$ \\
\hline California Towhee Melozone crissalis & $\mathrm{RB}$ & $11.3(1.3)$ & $<0.001$ & - & NC \\
\hline Lark Sparrow Chondestes grammacus & $\mathrm{RB}$ & $3.1(0.6)$ & $<0.001$ & - & $\mathrm{NC}$ \\
\hline White-crowned Sparrow Zonotrichia leucophrys & WR & $25.9(3.5)$ & 0.385 & $\mathrm{NC}$ & $\mathrm{NC}$ \\
\hline Dark-eyed Junco Junco hyemalis & WR & $9.6(0.7)$ & 0.459 & NC & NC \\
\hline Western Meadowlark Sturnella neglecta & $\mathrm{RB}$ & $7.0(2.8)$ & $<0.001$ & - & - \\
\hline Brown-headed Cowbird Molothrus ater & $\mathrm{MB}$ & $8.0(0.6)$ & $<0.024$ & - & $\mathrm{NC}$ \\
\hline Bullock's Oriole Icterus bullockii & $\mathrm{MB}$ & $6.3(1.3)$ & $<0.001$ & - & - \\
\hline
\end{tabular}

${ }^{a}$ Status: $\mathrm{RB}$, resident breeder; $\mathrm{MB}$, migratory breeder; WR, winter resident; $\mathrm{M}$, migratory.

variable. Our criterion for statistical significance of the parametric regressions was $p<0.05$. Application of linear regression will not always show the true nature of the yearly population trend and could therefore lead to incorrect conclusions about the status of a given bird population. For this reason, we also fitted a nonparametric regression model from the family of generalized additive models (Hastie and Tibshirani 1990), using a spline-smoothing function of the year effect. The general form of the model was
Mean count $=s($ year $)+$ route + residual error,

where $s$ (year) is the spline smoothing function for the yearly trend. Smoothing algorithms help clarify long-term trends, which can be obscured by both short-term fluctuations and measurement error (Siriwardena et al. 1998). The spline smoothing technique is a powerful statistical tool for assessing a regression curve's shape without blindly trying a large set of parametric functions (such as polynomials). We used the routines GLM and GAM 
in program $\mathrm{R}$ version 3.0.2 ( $\mathrm{R}$ Core Team 2013) for the parametric and nonparametric regressions, respectively. We used Akaike's information criterion (Burnham and Anderson 2002) and the percentage of deviance explained as statistical tools to assess goodness of fit for both regression models. The significance of spline regressions can be visually checked by assessing whether the confidence interval around the curve overlaps the null line in any year. As with linear regression, this visual assessment can indicate whether a species was increasing or decreasing. We therefore determined trends by visual inspection of the smoothed-curve regressions and drew conclusions about population trends by examining both fitted regressions.

\section{RESULTS}

Results from linear regression models showed significantly increasing trends for 16 species, significantly decreasing trends for 11 species, and no trend for 8 species over the 27 years of the study (Table 1).

The smoothed curves revealed the limitations of the linear analysis. While the results of the two analyses concurred for most species, for several they did not. Four species with increasing trends according to the linear analysis showed no clear pattern or normal fluctuation in the smoothed-curve results: the Western Kingbird, Hutton's Vireo, Orange-crowned Warbler, and Yellow-rumped Warbler (Appendix 1). For the Western Kingbird, the smoothed curve showed a sharp increase from about 1999 through 2006, which unduly influenced the linear analysis, but after 2006 there was a sharp decline in abundance (Appendix 1).

As assessed by their linear trend, six species decreased significantly, whereas their smoothed curves suggested long-term fluctuation and no clear trend of decrease or increase, or recovery following a decrease: the Oak Titmouse, Canyon Wren, Lesser Goldfinch, California Towhee, Lark Sparrow, and Brown-headed Cowbird (Appendix $1)$. For the most part the Canyon Wren decreased until around 2006 but recovered to average levels of abundance by 2012. Brown-headed Cowbird abundance was variable, an initial decrease being followed by recovery to normal numbers.

In no case did the sign of the long-term trend according to the linear regression and the smoothed curve differ, and in no case did the smoothed curve suggest a population trend where the linear regression did not. Linear regression overestimated the number of significant population trends. Overall, smoothed curves suggested that 12 species increased, 5 decreased, and 18 did not change (Table 1). Appendix 2 shows examples of fitted linear and smoothed-curve regression with residuals plotted for three species of low, medium, and high abundance. The differences in the mean counts per route in 1986 and 2012 are shown in Table 2 for both models, to aid in assessing relative changes in abundance across species.

\section{DISCUSSION}

Overall, 12 species appeared to have increased at SJER during the study: the California Quail, Anna's Hummingbird, Red-tailed Hawk, Acorn Woodpecker, Nuttall's Woodpecker, American Kestrel, Common Raven, Violet-green Swallow, White-breasted Nuthatch, Bewick's Wren, European Starling, and House Finch. Except for the starling, an invasive species that competes with native cavity nesters, this is good news, but whether these increases will be maintained in the face of anthropogenic stressors such as continuing climate change remains to be seen.

Five species decreased: the Blue-gray Gnatcatcher, Western Bluebird, Western Meadowlark, Bullock's Oriole, and California Scrub-Jay. Of these, the Blue-gray Gnatcatcher, Western Meadowlark, and Bullock's Oriole present cause for concern. The Blue-gray Gnatcatcher's trend decreased according to both the linear regression (significant; $p=0.003$ ) and the smoothed curve (Appendix 1). Results of the Breeding Bird Survey (BBS) for this species imply increases both rangewide and in the western states (2.64\% increase per year in the Western BBS Region from 1968 to 2012; Sauer et al. 2014), but trends vary across the range (Kershner and Ellison 2012). Blue-gray Gnatcatchers are documented Brown-headed Cowbird hosts at SJER, although parasitism rates are low (KLP unpubl. data). We recommend further study of this species.

Grassland bird species are showing consistent declines rangewide, the steepest declines of any group of species in North America (DeSante and George 1994, Knopf 1994, Vickery and Herkert 2001, Brennan and Kuvlesky 2005). The Western Meadowlark, an obligate grassland species, is no exception, according to the BBS declining significantly in both California and the Western BBS Region $(1.84 \%$ annual decrease in California, $1.41 \%$ decrease in the western region; Sauer et al. 2014). The causes for the declines are unknown, but habitat loss is thought to be the primary driver, and pesticides have also been implicated (NABCI 2013). Although habitat loss has not occurred at SJER and has been minimal in the 


\section{Avian Population Trends for California Oak Woodlands}

TABLE 2. Estimated difference in abundance between 1986 and 2012 used in assessing the relative magnitude of the change in mean count per route $(30$ stations per route) and SE among species.

\begin{tabular}{|c|c|c|}
\hline \multirow[b]{2}{*}{ Species } & \multicolumn{2}{|c|}{2012 minus 1986 mean difference (SE) } \\
\hline & Linear regression & Smoothed curve regression \\
\hline California Quail & $12.23(1.74)$ & $37.64(2.31)$ \\
\hline Mourning Dove & $-1.69(1.19)$ & $-1.21(1.63)$ \\
\hline Anna's Hummingbird & $2.39(0.45)$ & $2.56(0.61)$ \\
\hline American Kestrel & $0.70(0.24)$ & $1.93(0.32)$ \\
\hline Turkey Vulture & $-0.75(1.35)$ & $0.26(1.67)$ \\
\hline Red-tailed Hawk & $3.38(0.82)$ & $5.84(1.11)$ \\
\hline Acorn Woodpecker & $26.01(2.41)$ & $71.23(3.14)$ \\
\hline Nuttall's Woodpecker & $3.08(0.48)$ & $3.49(0.65)$ \\
\hline Ash-throated Flycatcher & $-0.22(0.96)$ & $-1.99(1.24)$ \\
\hline Western Kingbird & $3.11(0.93)$ & $0.00(1.27)$ \\
\hline Hutton's Vireo & $1.76(0.22)$ & $0.61(0.29)$ \\
\hline California Scrub-Jay & $-17.27(1.13)$ & $-0.46(1.57)$ \\
\hline Common Raven & $23.53(0.95)$ & $23.47(1.20)$ \\
\hline Violet-green Swallow & $5.51(1.85)$ & $8.65(2.52)$ \\
\hline Oak Titmouse & $-11.78(1.30)$ & $22.91(1.75)$ \\
\hline Bushtit & $-0.03(0.80)$ & $-0.12(1.14)$ \\
\hline White-breasted Nuthatch & $6.13(0.83)$ & $7.31(1.24)$ \\
\hline Canyon Wren & $-1.46(0.34)$ & $-0.52(0.45)$ \\
\hline House Wren & $-0.95(0.82)$ & $6.90(1.11)$ \\
\hline Bewick's Wren & $12.60(0.85)$ & $7.44(1.15)$ \\
\hline Blue-gray Gnatcatcher & $-0.53(0.24)$ & $-1.10(0.34)$ \\
\hline Ruby-crowned Kinglet & $0.01(0.61)$ & $7.29(0.75)$ \\
\hline Western Bluebird & $-1.99(0.64)$ & $-1.20(0.86)$ \\
\hline European Starling & $3.18(1.76)$ & $3.25(2.54)$ \\
\hline House Finch & $4.96(1.14)$ & $17.44(1.51)$ \\
\hline Lesser Goldfinch & $-2.36(0.96)$ & $-0.61(1.29)$ \\
\hline Orange-crowned Warbler & $0.84(0.39)$ & $3.90(0.56)$ \\
\hline Yellow-rumped Warbler & $7.46(2.00)$ & $35.99(2.66)$ \\
\hline California Towhee & $-6.55(0.65)$ & $-1.25(0.91)$ \\
\hline Lark Sparrow & $-2.56(0.39)$ & $-0.88(0.52)$ \\
\hline White-crowned Sparrow & $-1.17(1.78)$ & $4.78(2.44)$ \\
\hline Dark-eyed Junco & $-0.51(0.92)$ & $3.73(1.22)$ \\
\hline Western Meadowlark & $-4.25(0.70)$ & $-4.61(1.00)$ \\
\hline Brown-headed Cowbird & $-1.18(0.69)$ & $-2.01(0.88)$ \\
\hline Bullock's Oriole & $-3.66(0.61)$ & $-3.58(0.83)$ \\
\hline
\end{tabular}

surrounding area, this species disappears in late summer and early fall, and little is known about its movements (Purcell et al. 2007). We recommend research into the causes of the decline in numbers of Western Meadowlarks.

The Bullock's Oriole also declined significantly in our study area. While there are no concerns for the species rangewide, habitat destruction and pesticides are believed to affect local populations (Flood et al. 2016). Livestock grazing may affect abundance of this species. Results from 10 years of spot-mapping censuses in grazed and ungrazed plots at SJER revealed that Bullock's Orioles were less abundant on the grazed site (Verner et al. 1997). BBS results show a significant decreasing trend for California $(1.58 \%$ decrease per year from 1968 to 2012; Sauer et al. 2014), in agreement with our results, and suggest further investigation of this poorly studied species is needed.

For the Western Bluebird, both linear regression and the smoothed curve showed a decreasing trend; however, the smoothed curve suggests a strong increase after 2005 (Appendix 1). While bluebirds have not yet reached their previous levels, there does not yet appear to be cause for concern for this species. Nest boxes were placed at SJER beginning in 1989, with numbers and locations of boxes varying during that time as used in various studies. As bluebirds use nest boxes readily, variability in box availability, while probably 
not driving the observed pattern, could add to variability in bluebird numbers. We recommend continued monitoring of this species.

Results for the California Scrub-Jay were especially interesting. West Nile virus (WNV) was first detected in California in 2003 (Reisen et al. 2004) and became widespread in the state in the summer of 2004, with documented impacts on avian populations beginning in 2004 (Koenig et al. 2007, Wheeler et al. 2009). In California, nearly $60 \%$ of California Scrub-Jays found dead tested positive for WNV, and mortality after experimental infection was greater than $80 \%$. The species' population in the Central Valley has declined significantly (Wheeler et al. 2009). However, 30\% of free-living birds tested positive for WNV antibodies (Wheeler et al. 2009), and several studies have shown that scrub-jays that survive initial infection are protected by long-lasting immunity (Reisen et al. 2006, 2009, Wheeler et al. 2009). Our results coincide with these findings. At SJER, beginning around 2003, California Scrub-Jays decreased steeply, then began recovering in 2009. Although the response to WNV likely didn't begin until 2004, we believe the pattern we observed was an example of population decline due to WNV, followed by recovery, as residual birds with genetic resistance reconstituted the population.

Oak Titmice are also susceptible to WNV (Airola et al. 2007, Wheeler et al. 2009). Titmice scored in the highest-risk category and their population declined in three of four regions in California, although not in ours. Wheeler et al. (2009) cautioned that robust data for this species are lacking and suggested it deserves additional study. We did not detect any long-term adverse effects of WNV on Oak Titmice. Although our data show a decline starting in 2003, we also saw a stronger decrease from 1991 through 1997, and increases since 2006 compensate for earlier declines.

The increasing trend of the Common Raven is noteworthy. This species is generally increasing rangewide (according to the BBS, 2.3\% per year survey-wide from 1968 to 2013; Sauer et al. 2014). It was not recorded at SJER prior to 1952 but has been recorded every year since 1965. The raven is now a common year-round resident at SJER, and it is California's corvid least susceptible to WNV (Koenig et al. 2007, Reisen et al. 2009, Wheeler et al. 2009). A generalist, the raven demonstrates considerable ingenuity in exploiting diverse habitats (Boarman and Heinrich 1999). Because it is a predator, including on nests, increases in its abundance may depress the abundance and reproductive success of some other birds with which it occurs.

The population of the Acorn Woodpecker, the most commonly detected species at SJER, also increased over the 27 years of the study. It is considered a keystone species because of the cavities it excavates for nesting and the acorns it stores, both of which are used by many other wildlife species (Purcell 2011). If the Acorn Woodpecker were to decrease in abundance we would expect cascading effects throughout the ecosystem. It is therefore a key species to monitor.

The results of the linear-trend analysis exposed the limitations of this method due to the loss of information resulting from imposing a linear structure on data that are inherently nonlinear. Other researchers have also recognized the limitations of linear analytic methods and have recommended nonlinear approaches to analysis of population trends (James et al. 1996, Francis and Hussell 1998, Siriwardena et al. 1998, Farmer and Hussell 2008). In our study, results from the linear regression were misleading or unequivocally incorrect in some cases. Examination of the smoothed trend curves revealed some particularly interesting results, including information on the direction and timing of changes and underlying patterns. Most species' abundance was highly variable, with long-term fluctuations in numbers. The spline-smoothed curves revealed oscillations in species' abundance that may represent normal population dynamics (Hussell et al. 1992) or, for initially declining species, evidence of recovery (Hill and Hagan 1991). These fluctuations likely indicate normal increases and decreases expected in otherwise stable populations that are tracking resources we did not measure, such as food availability, or that we do not analyze here, such as climate (Purcell and Mori 2018).

Finally, we offer a few words of caution. First, while we have documented population trends, our results do not explain the causes of these trends. We lack long-term data on productivity and survival to parallel our trend data. Additional research is needed to provide answers, with a focus on habitat requirements, demographics of declining populations, and responses to abiotic factors such as local weather and global climate patterns (Purcell and Mori 2018). Second, because trends may differ depending on whether sampling is done in the center of a distribution or near its edge, our conclusions should not be interpreted as representing rangewide or statewide trends in abundance.

Our results underscore the need for long-term 
research and monitoring. Our smoothed-curve results showed fluctuations suggesting the normal variability expected in a population, which could be seen only through long-term monitoring. Short-term monitoring, even of up to ten or more years, provides only a piece of the picture, and that piece can easily be misleading with respect to the status of a population. Long-term monitoring such as ours can provide warnings of undesirable environmental change and suggest actions to help mitigate potential negative consequences.

\section{ACKNOWLEDGMENTS}

We thank Jerry Verner for having the vision to initiate this work, which still continues. We are deeply indebted to the following field assistants who helped us collect these data: M. Anderson, L. Arnow, D. P. Backstrom, S. Balch, S. Bloomfield, M. Brady, K. Brubaker, K. Burton, C. Cutler, J. Davis, S. Deal, D. Drynan, A. Fogg, M. Georgeff, B. Gibson, K. Granillo, E. Hammond, B. Komanski, K. Kuska, Z. Labinger, P. Landres, D. Lipp, J. Lovio, R. MacDonald, W. Maynard, D. Maxwell, K. Mazzocco, R. Miller, D. Nelson, K. Nelson, B. North, C. Pidgeon, R. Reynolds, J. Seay, T. Schantz, M. Smith, T. Smith, C. Steggall, J. Sterling, S. Sutton-Mazzocco, K. Suryan, R. Suryan, R. Suydam, D. Taylor, T. Tennant, D. Tibor, J. Tietz, J. Turner, and E. Whistler. Eric McGregor prepared Figure 1. The manuscript benefitted from constructive reviews by Colleen Handel, Rodney Siegel, and William Tietje. Funding for this research was provided by the USDA Forest Service, Pacific Southwest Research Station, Fresno, California, and the USDA Forest Service Region 5.

\section{LiTERATURE CITED}

Airola, D. A., Hampton, S, and Manolis, T. 2007. Effects of West Nile virus on sensitive species in the lower Sacramento Valley, California: An evaluation using Christmas Bird Counts. Central Valley Bird Club Bull. 10:1-21.

Askins, R. A., Lynch, J. R., and Greenberg, R. 1990. Population declines in migratory birds in eastern North America. Curr. Ornithol. 7:1-57.

Ballard, G., Geupel, G. R., Nur, N., and Gardali, T. 2003. Long-term declines and decadal patterns in population trends of songbirds in western North America, 1979-1999. Condor 105:737-755; doi $10.1650 / 7131$.

Boarman, W. I., and Heinrich, B. 1999. Common Raven (Corvus corax), in The Birds of North America Online (A. Poole and F. Gill, eds.), no. 476. Cornell Lab. Ornithol., Ithaca, NY; doi 10.2173/bna.476.

Brennan, L. A., and Kuvlesky, W. P., Jr. 2005. North American grassland birds: An unfolding conservation crisis?
J. Wildl. Mgmt. 69:1-13; doi 10.2193/0022-541X(2 005)069<0001:NAGBAU>2.0.CO;2.

Burnham, K. P., and Anderson, D. R. 2002. Model Selection and Multimodel Inference: A Practical Information-Theoretic Approach, 2nd ed. Springer, New York.

DeSante, D. F., and George, T. L. 1994. Population trends in the landbirds of western North America. Studies Avian Biol. 15:173-190.

Dunn, E. H. 2002. Using decline in bird populations to identify needs for conservation action. Conserv. Biol.16:1632-1637; doi10.1046/j.1523-1739.2002. 01250.x.

Farmer, C. J., and Hussell, D. J. T. 2008. The raptor population index in practice, in State of North America's birds of prey (K. L. Bildstein, J. P. Smith, E. R. Inzunza, and R. R. Veit, eds.), pp. 165-177. Ser. Ornithol. No. 3, Am. Ornithol. Union.

Flood, N. J., Schlueter, C. L., Reudink, M. W., Pyle, P., Patten, M. A., Rising, J. D., and Williams, P. L. 2016. Bullock's Oriole (Icterus bullockii), in The Birds of North America Online (P. G. Rodewald, ed.), no. 416. Cornell Lab. Ornithol., Ithaca, NY; doi 10.2173/bna.416.

Francis, C. M., and Hussell, D. J. T. 1998. Changes in numbers of landbirds counted in migration at Long Point Bird Observatory, 1961-1997. Bird Popul. 4:37-66.

Hastie, T., and Tibshirani, R. 1990. Generalized Additive Models. Chapman and Hall, London.

Hill, N. P., and Hagan, J. M. I. 1991. Population trends of some northeastern North American landbirds: A half century of data. Wilson Bull. 103:165-182.

Holmes, R. T., and Sherry, T. W. 1988. Assessing population trends of New Hampshire forest birds: Local vs. regional patterns. Auk 105:756-768.

Hussell, D. J. T., Mather, M. H., and Sinclair, P. H. 1992. Trends in numbers of tropical- and temperatewintering migrant landbirds in migration at Long Point, Ontario 1961-1988, in Ecology and Conservation of Neotropical Migrant Landbirds (J. M. Hagan and D. W. Johnston, eds.), pp. 101-114. Smithsonian Inst. Press, Washington, DC.

James, F. C., McCulloch, C. E., and Wiedenfeld, D. A. 1996. New approaches to the analysis of population trends in land birds. Ecology 77:13-27; doi $10.2307 / 2265650$.

Joseph, L. N., Field, S. A., Wilcox, C., and Possingham, H. P. 2006. Presence-absence versus abundance data for monitoring threatened species. Conserv. Biol. 20:1679-1687; doi 10.1111/j.15231739.2006.00529.x.

Knopf, F. L. 1994. Avian assemblages on altered grasslands. Studies Avian Biol. 15:247-257.

Kershner, E. L., and Ellison, W. G. 2012. Blue-gray Gnatcatcher (Polioptila caerulea), in The Birds of North America Online (A. Poole, ed.), no. 23. Cornell Lab. Ornithol., Ithaca, NY; doi 10.2173/ bna.23.

Koenig, W. E., Marcus, L., Scott, T. W., and Dickinson, 
J. L. 2007. West Nile virus and California breeding bird declines. EcoHealth 4:18-24; doi 10.1007/ s10393-007-0086-4.

Marsh, D. M., and Trenham, P. C. 2008. Current trends in plant and animal population monitoring. Conserv. Biol. 22:647-635; doi 10.1111/j.15231739.2008.00927.x.

North American Bird Conservation Initiative, U.S. Committee (NABCI). 2013. The State of the Birds 2013 report on private lands. USDI, Washington, DC; www.stateofthebirds.org/2013.

North American Bird Conservation Initiative, U.S. Committee (NABCI). 2014. The State of the Birds 2014 report. USDI, Washington, DC; www. stateofthebirds.org/2014/.

Purcell, K. L. 2011. Long-term avian research at the San Joaquin Experimental Range: Recommendations for monitoring and managing oak woodlands. For. Ecol. Mgmt. 262:12-19; doi 10.1016/j.foreco.2010.07.039.

Purcell, K. L., and Mori, S. R. 2018. Modeling the response of oak woodland birds to changing climate using 27 years of monitoring data, in Trends and traditions: Avifaunal change in western North America (W. D. Shuford, R. E. Gill Jr., and C. M. Handel, eds.), pp. 344-373. Studies of Western Birds 3. Western Field Ornithologists, Camarillo, CA; doi 10.21199/SWB3.19

Purcell, K. L., Mori, S. R., and Chase, M. K. 2005. Design considerations for monitoring avian abundance using point counts: Examples from California oak woodlands. Condor 107:305-320; doi 10.1650/7595.

Purcell, K. L., Drynan, D. A., and Mazzocco, K. M. 2007. Vertebrate fauna of the San Joaquin Experimental Range, California: An annotated checklist based on 70 years of observations; www.fs.fed.us/ psw/programs/snrc/partners/sjer/SJERannotated_ checklist_September_2007.pdf.

R Core Team. 2013. R: A language and environment for statistical computing. R Foundation for Statistical Computing, Vienna, Austria; www.R-project.org/.

Reisen, W. [K.], Lothrop, H., Chiles, R., Madon, M., Cossen, C., Woods, L., Husted, S., Kramer, V., and Edman, J. 2004. West Nile virus in California. Emerg. Infect. Dis. 10:1369-1378; doi 10.3201/ eid1008.040077.

Reisen, W. K., Fang, Y., Lothrop, H. D., Martinez, V. M., Wilson, J., O'Connor, P., Carney, R., CahoonYoung, B., et al. 2006. Overwintering of West Nile virus in southern California. J. Med. Entomol. 43:344-355; doi10.1093/medent/43.2.344.

Reisen, W. K., Carroll, B. D., Takahashi, R., Fang, Y.,
Garcia, S., Martinez, V. M., and Quiring, R. 2009. Repeated West Nile virus epidemic transmission in Kern County, California, 2004-2007. J. Med. Entomol. 46:139-157; doi 10.1603/033.046.0118.

Robbins, C. S., Sauer, J. R., Greenberg, R. S., and Droege, S. 1989. Population declines in North American birds that migrate to the Neotropics. Proc. Natl. Acad. Sci. USA 86:7658-7662.

Robbins, C. S., Sauer, J. R., and Peterjohn, B. G. 1993. Population trends and management opportunities for neotropical migrants, in Status and management of neotropical migratory birds (D. M. Finch and P. W. Stengel, eds.), pp. 17-23. Gen. Tech. Rep. RMGTR-229. USDA For. Serv., Rocky Mountain For. Range Exp. Stn., Fort Collins, CO; www.fs.usda. gov/treesearch/pubs/22803.

Sauer, J. R., Hines, J. E., Fallon, J. E., Pardieck, K. L., Ziolkowski, D. J., Jr., and Link, W. A. 2014. The North American breeding bird survey, results and analysis 1966-2012, version 02.19.2014. USGS Patuxent Wildl. Res. Center, Laurel, MD.

Siriwardena, G. M., Baillie, S. R., Buckland, S. T., Fewster, R. S., Marchant, J. H., and Wilson, J. D. 1998. Trends in the abundance of farmland birds: A quantitative comparison of smoothed Common Birds Census indices. J. Appl. Ecol. 35:24-43; doi 10.1046/j.1365-2664.1998.00275.x.

Terborgh, J. W. 1989. Where Have All the Birds Gone? Essays on the Biology and Conservation of Birds that Migrate to the American Tropics. Princeton Univ. Press, Princeton, NJ.

Verner, J., and Milne, K. A. 1989. Coping with sources of variability when monitoring population trends. Ann. Zool. Fennici 26:191-199.

Verner, J., Purcell, K. L., and Turner, J. G. 1997. Bird communities in grazed and ungrazed oak-pine woodlands at the San Joaquin Experimental Range, in Proceedings of a symposium on oak woodlands: Ecology, management, and urban interface issues (N. H. Pillsbury, J. Verner, and W. D. Tietje, tech. coords.), pp. 381-390. Gen. Tech. Rep. PSW-GTR-160. USDA For. Serv., Pacific Southwest Res. Stn., Albany, CA; www.fs.fed. us/psw/publications/documents/psw_gtr160/.

Vickery, P. D., and Herkert, J. R. 2001. Recent advances in grassland bird research: Where do we go from here? Auk 118:11-15; doi 10.1642/0004-8038(2001)118 [0011:RAIGBR]2.0.CO;2.

Wheeler, S. S., Barker, C. M., Fang, Y., Armijos, M. V., Carroll, B. D., Husted, S., Johnson, W. O., and Reisen, W. K. 2009. Differential impact of West Nile virus on California birds. Condor 111:1-20; doi 10.1525/cond.2009.080013. 

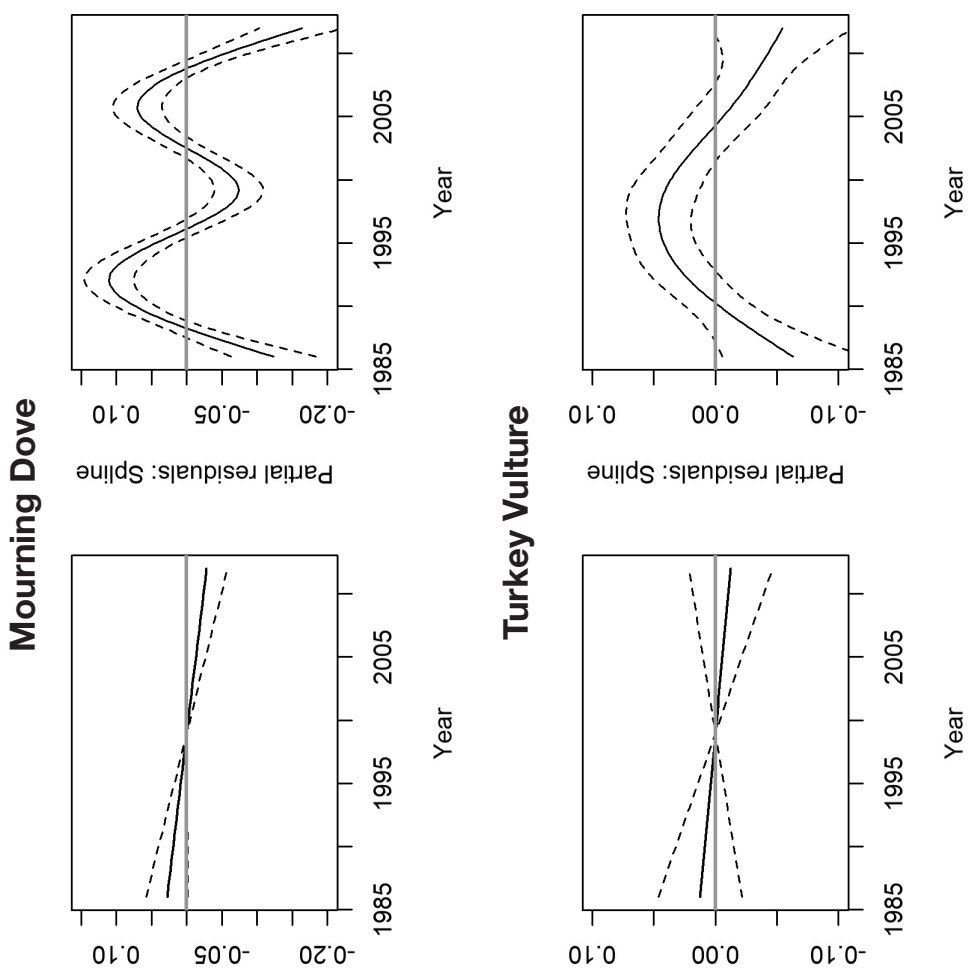

גeəu!̣ :s|enp!̣səd ןe!̣ued

גeəu!̣ :s|enp!səd |e!nued
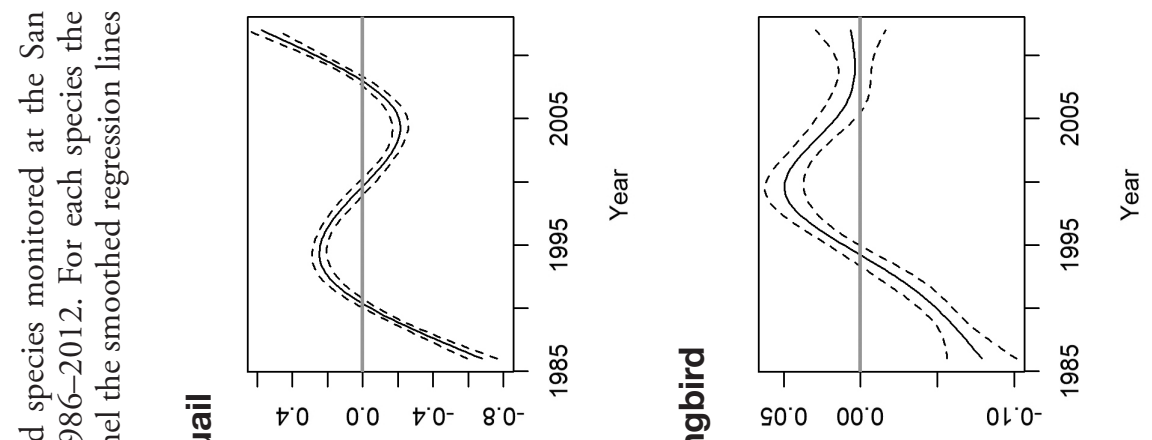

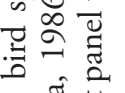

थิ

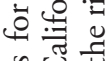

ㅇํำ

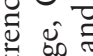

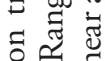

굴

艺孚

의

- $\overline{0}$ चे

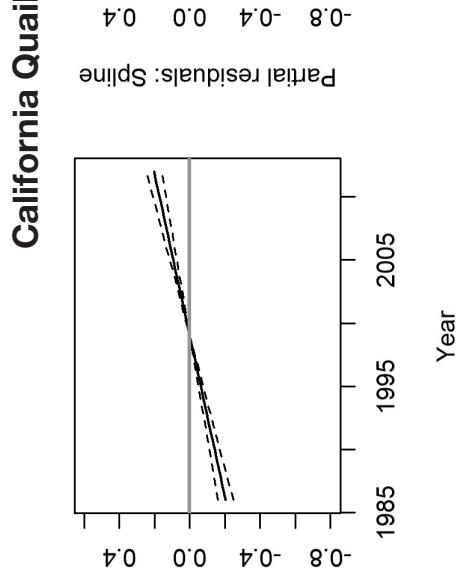

әu!|ds :sjenp!səd ןe!nued

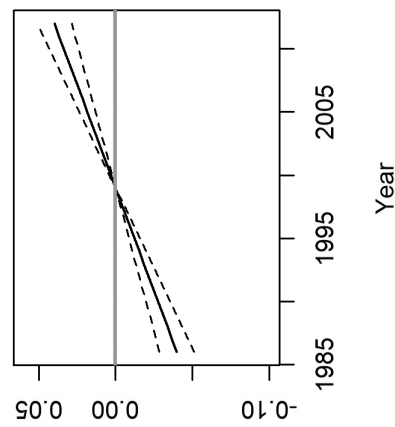

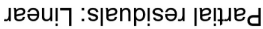

ıeəu!̣ :s|enp!səı ןe!̣ued 


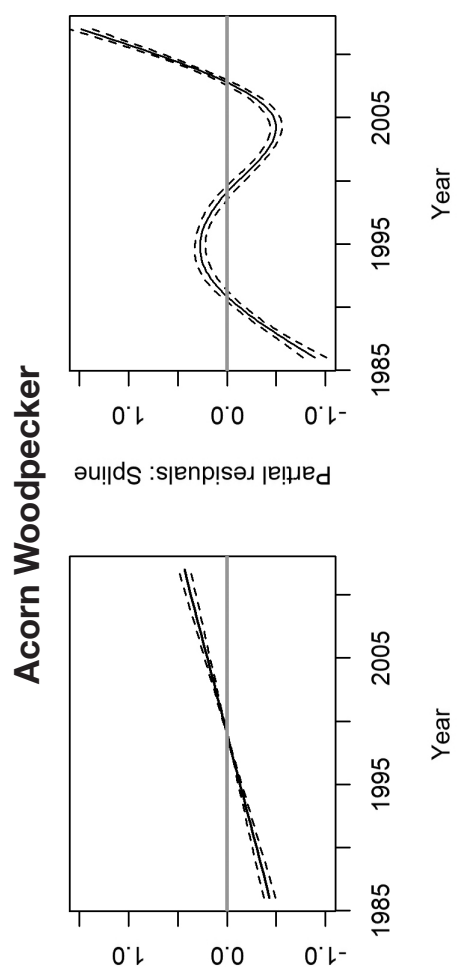

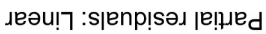

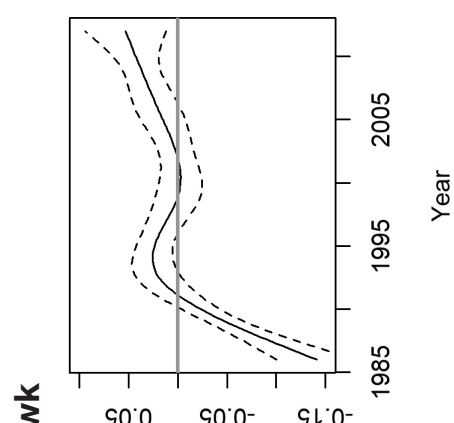

әu!|ds :s|enp!səd |e!̣ued

일

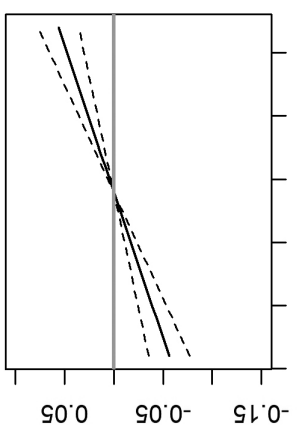

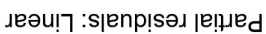

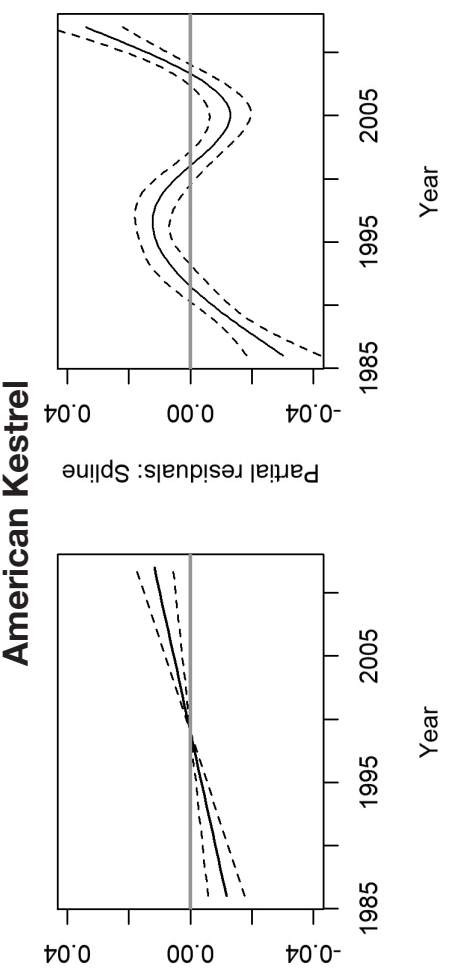

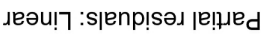

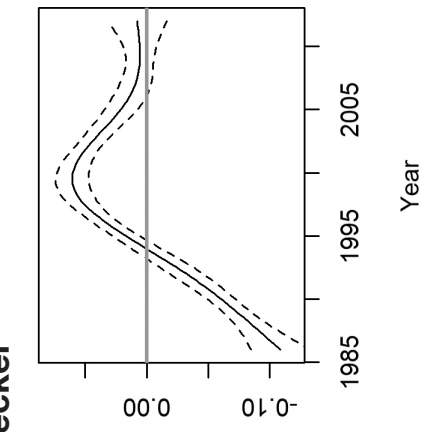

əu!|ds :s|enp!səd je!̣ued

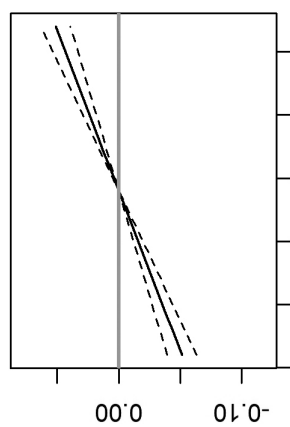

נeәu! 7 :s|enp!səd ןe!ned

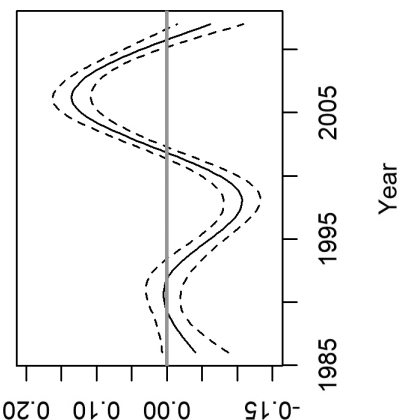

әu!|ds :s|enp!səג je!̣ued

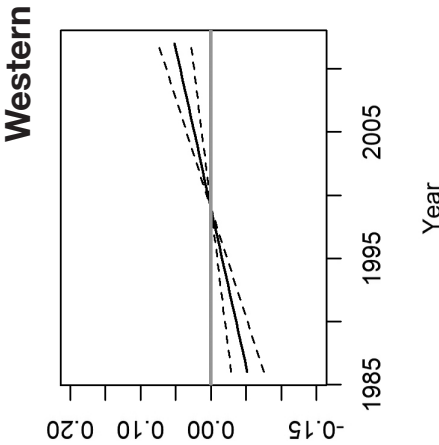

ıeəu!̣ :s|enpı̣səג ןe!̣ued

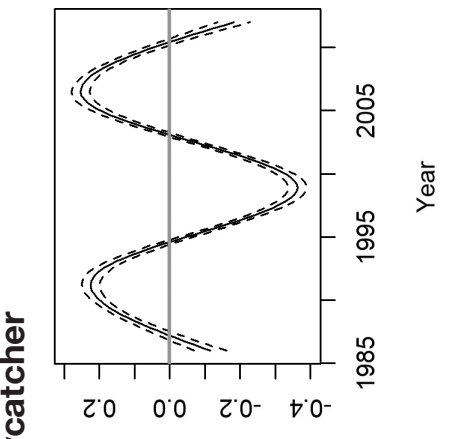

au!lds :sjenp!sad je!uted

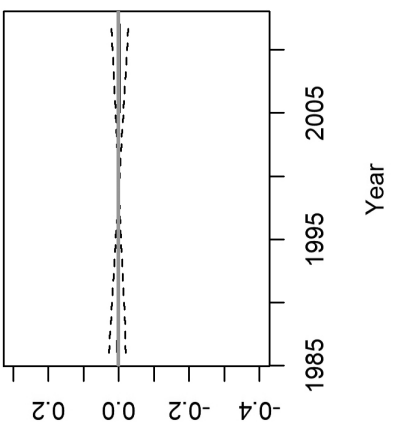

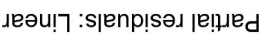




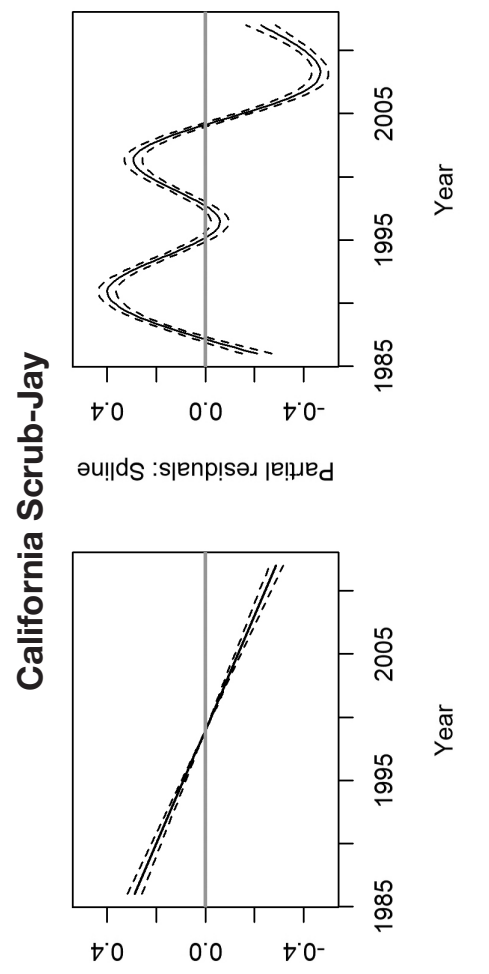

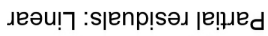

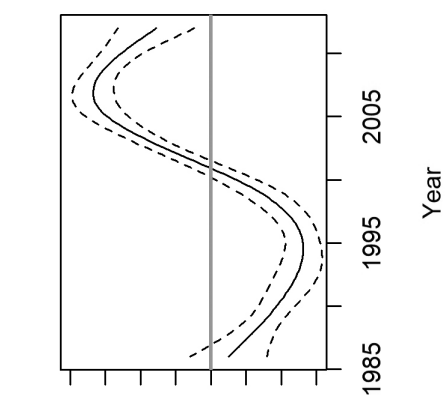

일
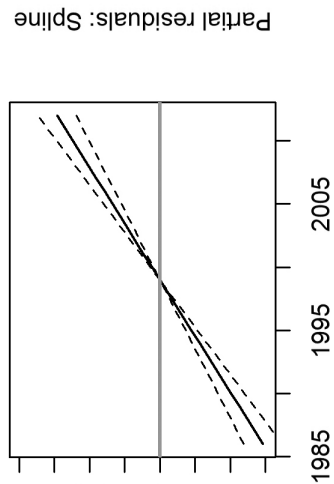

$\begin{array}{llll}70^{\circ} & 20^{\circ} 0 & 00^{\circ} 0 & 80^{\circ} 0^{-}\end{array}$

נeәu!̣ :s|enp!sad ןẹued

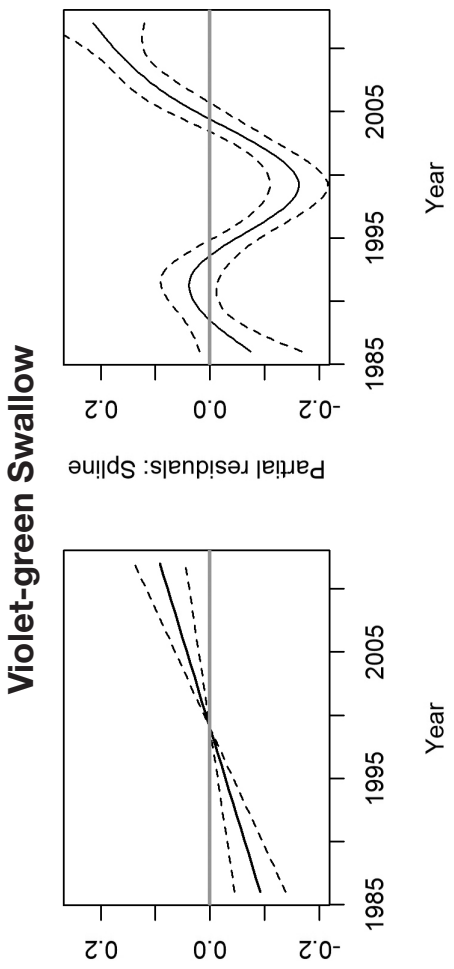

ıeəu!̣ :s|enp!səd ןe!ned

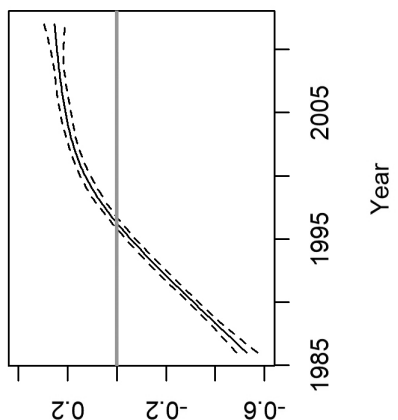

әu!|ds :s|enpısəı ןe!̣ued
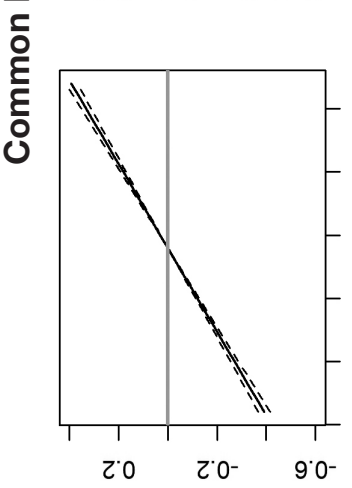

נeәu! 7 :s|enpịsal je!njed
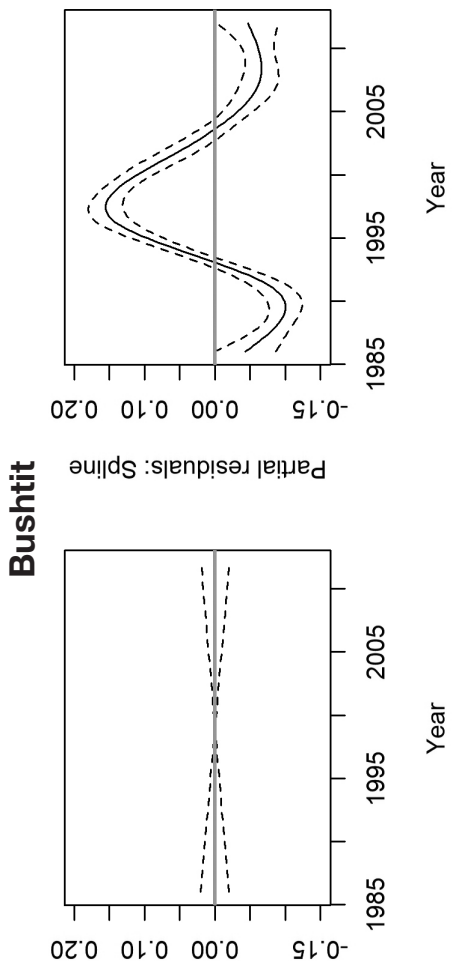

נeәu! 7 :s|enpisad ןe!jued
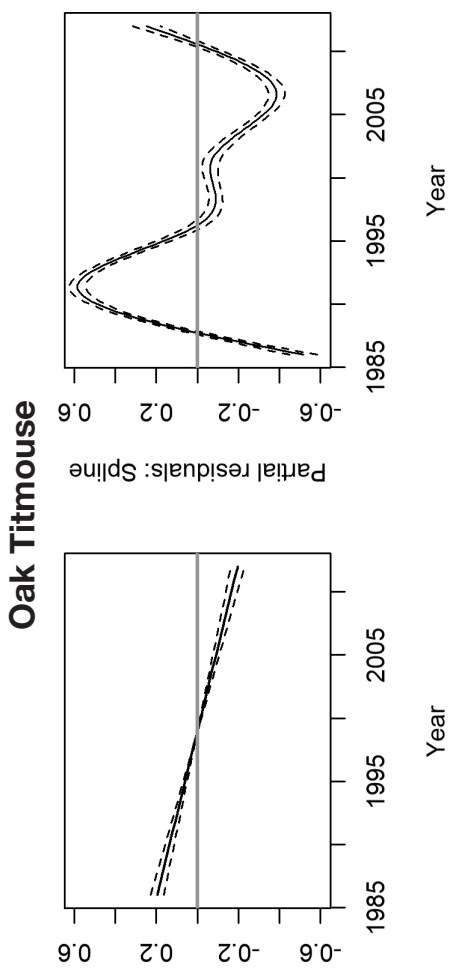

נeәu! 7 :s|enp!sal ןe!pued 


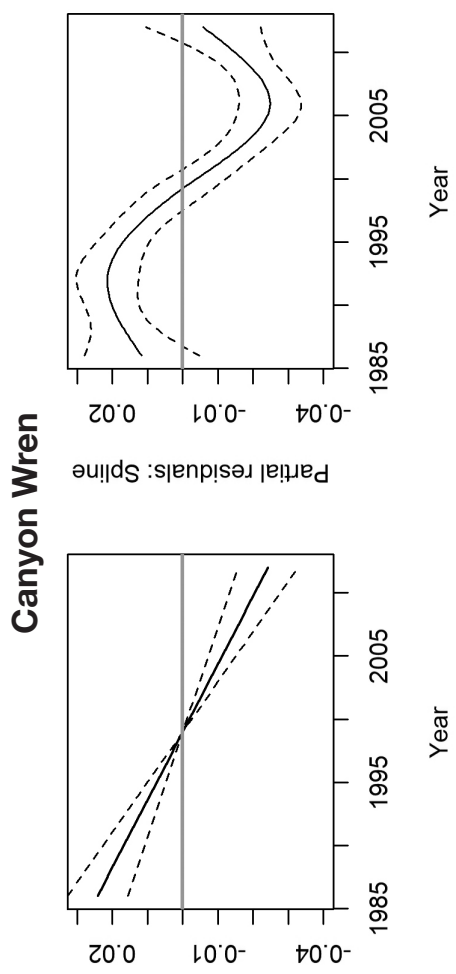

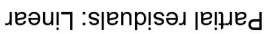

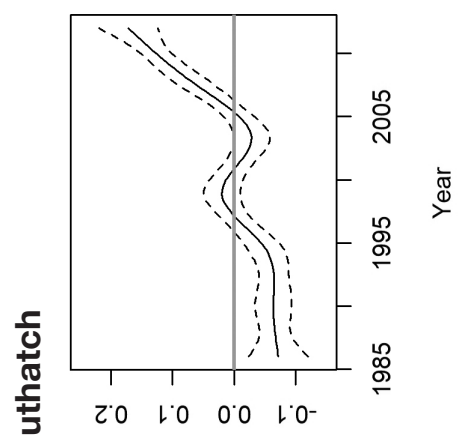

әu!|ds :s|enp!səג |e!nued

엉

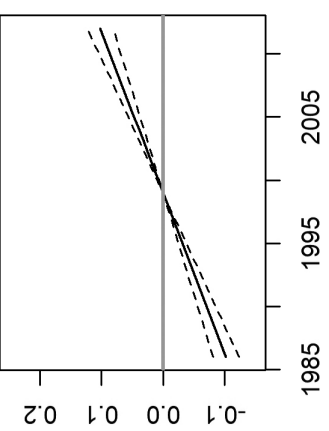

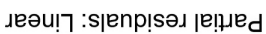
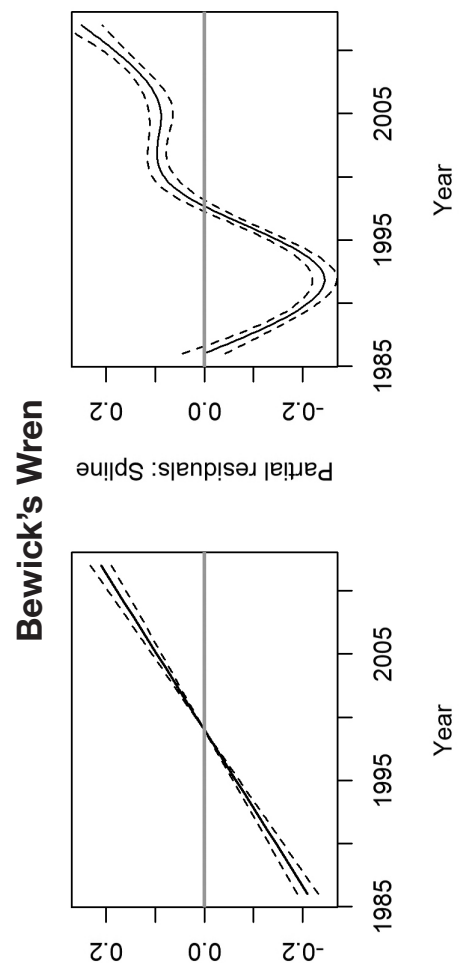

נeәu!̣ :s|enp!sad je!nued
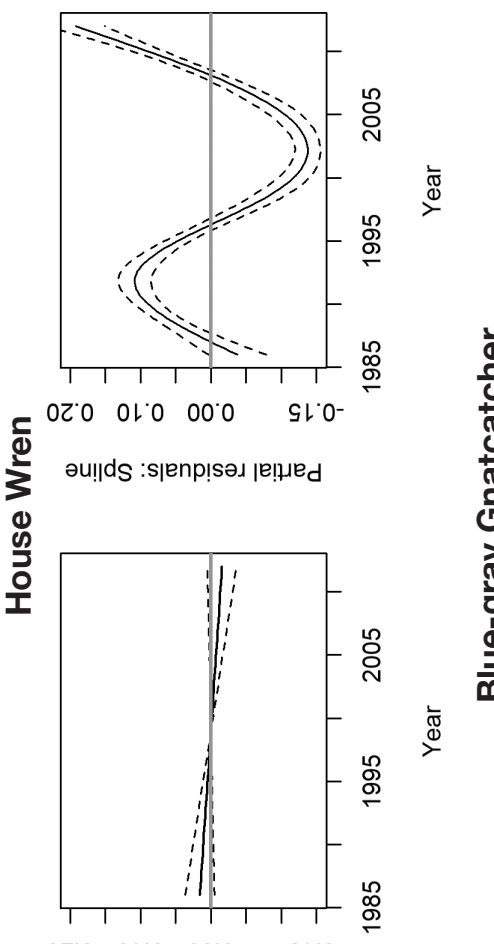

OZ.O OL.O $00^{\circ} 0$ SLO-

נeәu!̣ : s|enp!sal ןe!ned

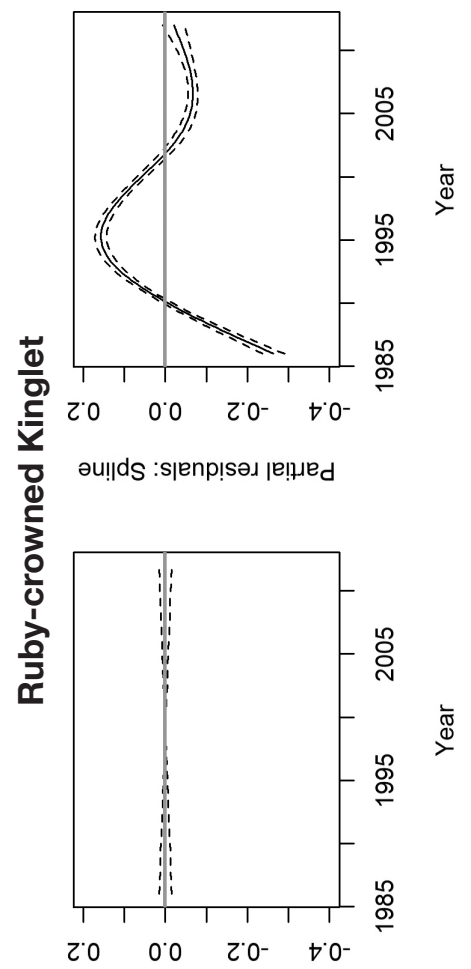

деәu!̣ :s|enp!sad je!̣ued

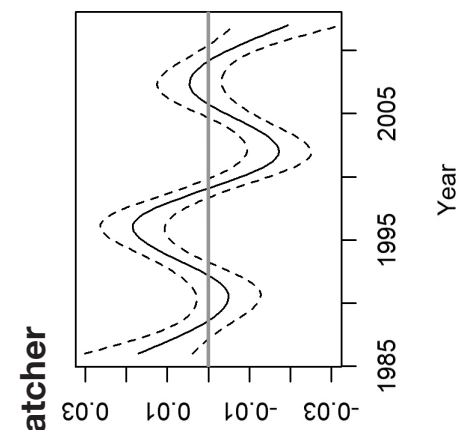

әu!|ds :s|enp!sad |e!nued

힌

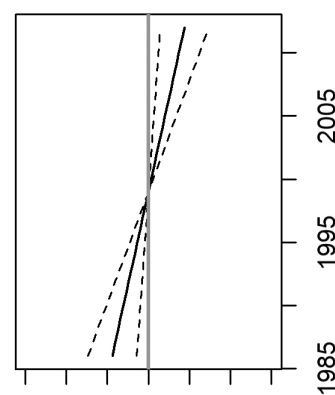

$80^{\circ} 0{ }^{\circ} 0^{\circ} \mathrm{HO}^{\circ} \mathrm{O}^{-} \mathrm{E0} \mathrm{O}^{\circ}$

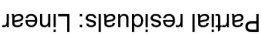




\section{Avian Population Trends for California Oak Woodlands}

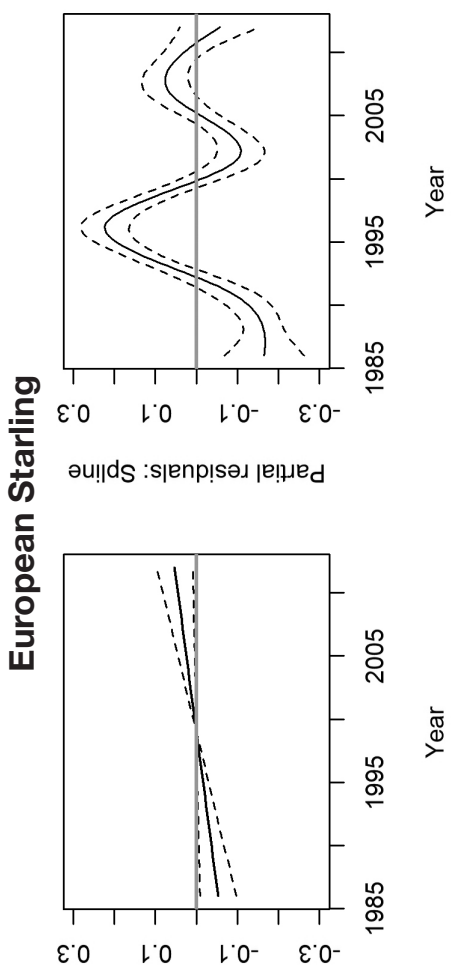

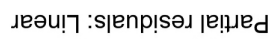

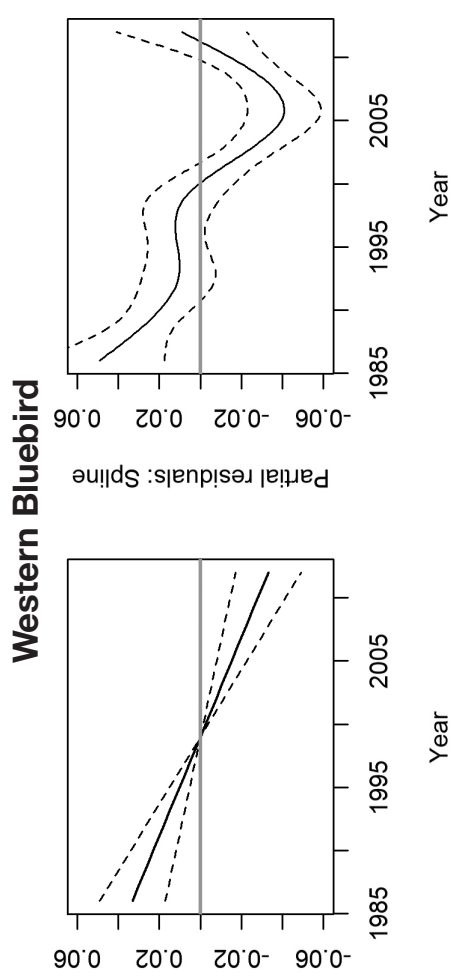

נeәu!̣ :s|enp!sad ןe!nued
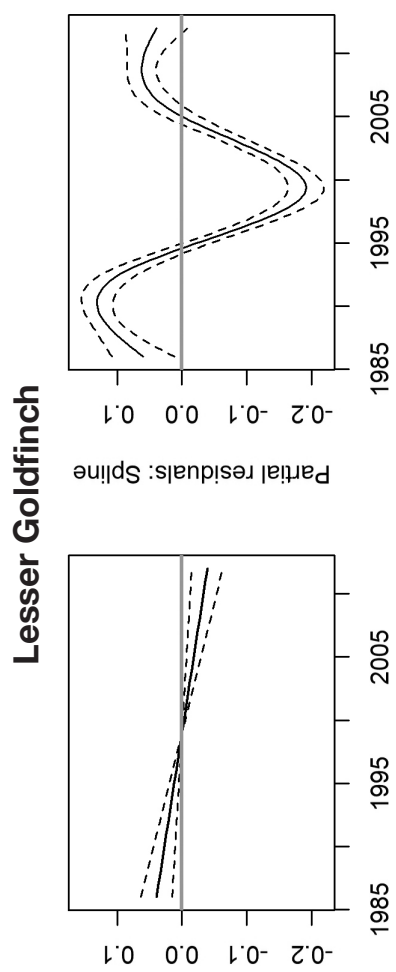

ıеәu!̣ : s|enp!̣sa je!̣ued

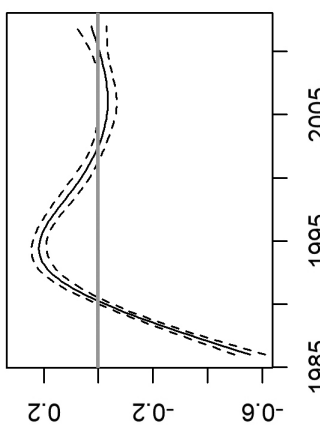

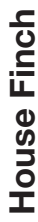
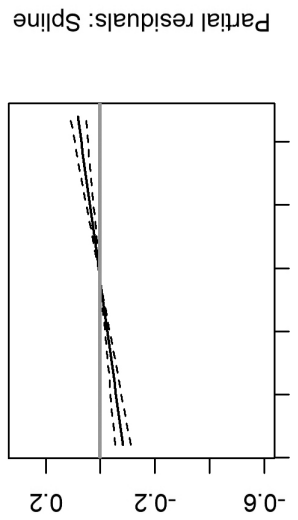

ıeəu!̣ :s|enp!̣sa je!̣ued

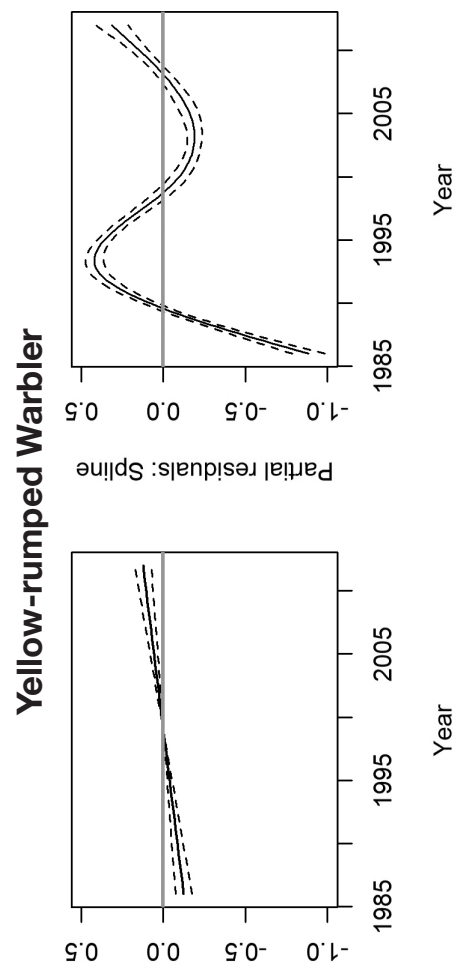

גeәu!̣ :s|enp!̣səd ןe!̣ued

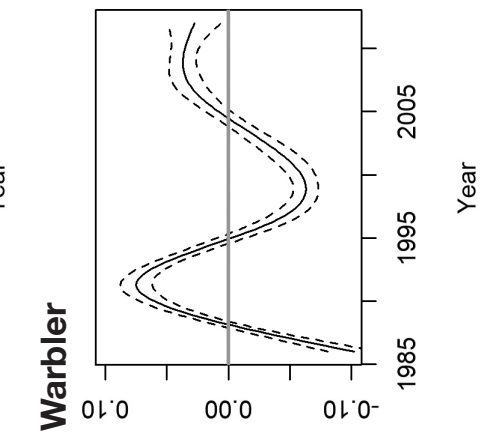

어ํ

əu

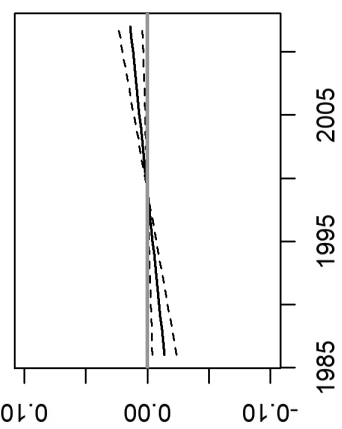

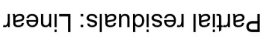



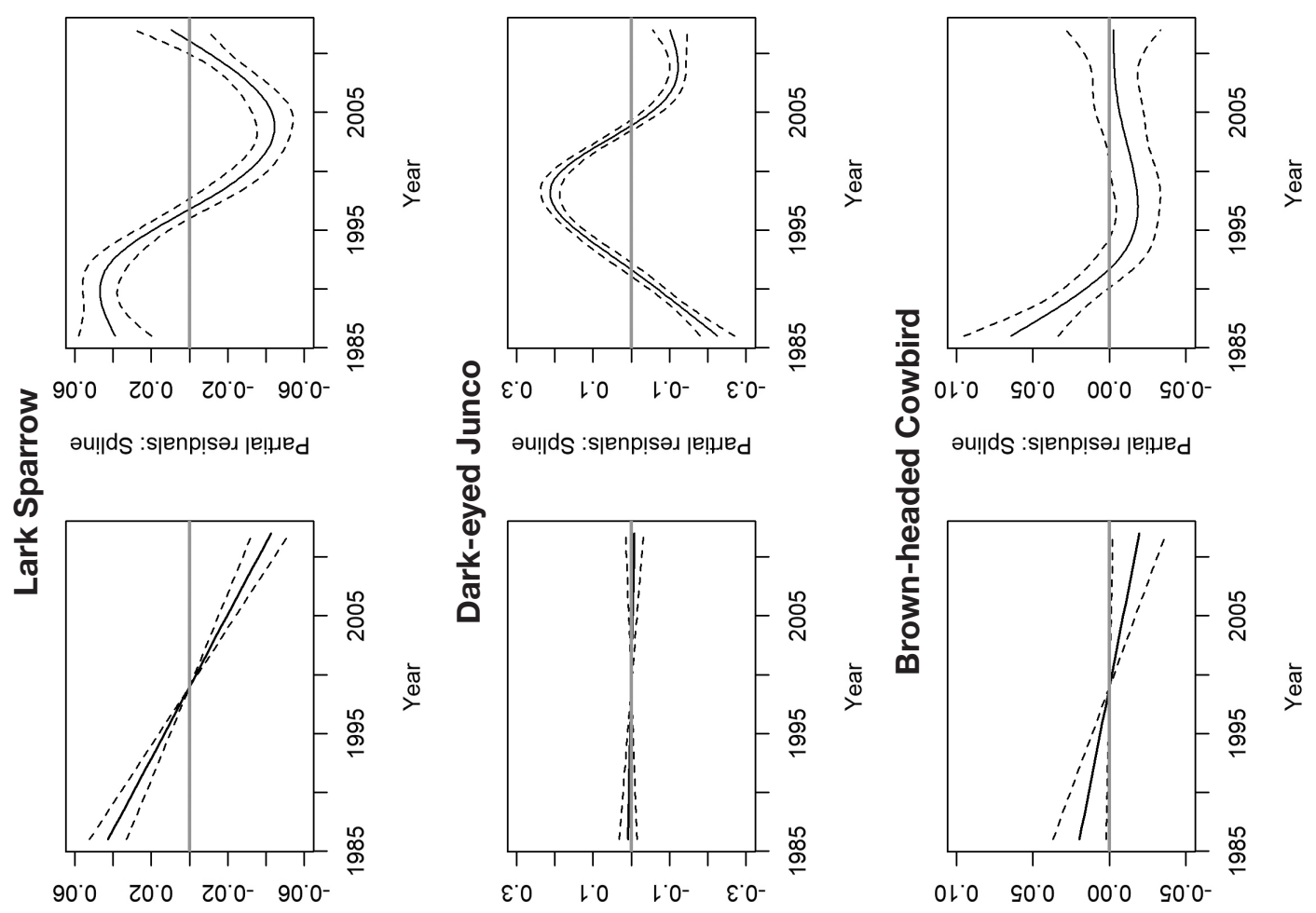

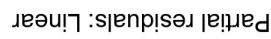

נeәu! : s|enp!̣səd ןe!ued

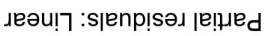

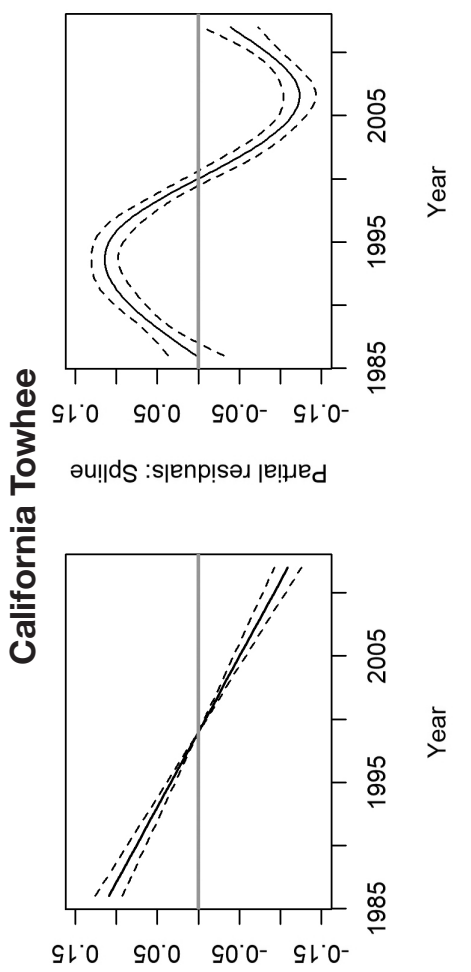

נeәu!̣ : s|enp!sad |e!nued

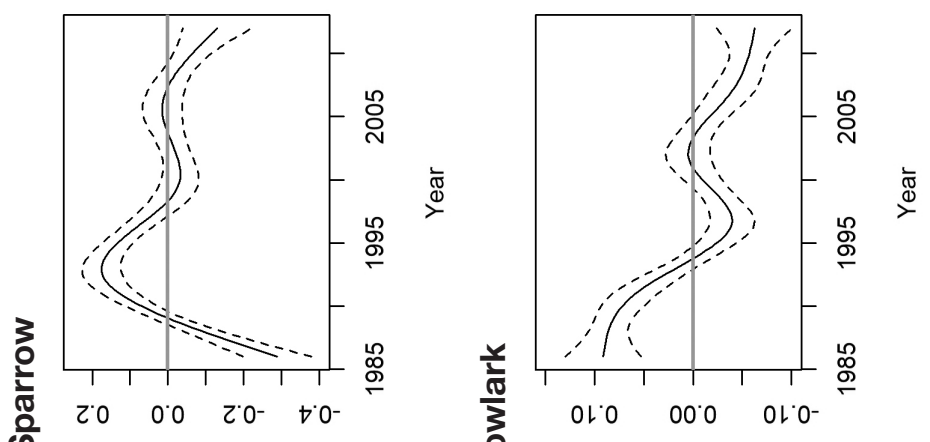

əu!|ds :s|enp!səd |e!̣ued

әu!|ds :s|enp!səı ןe!jued

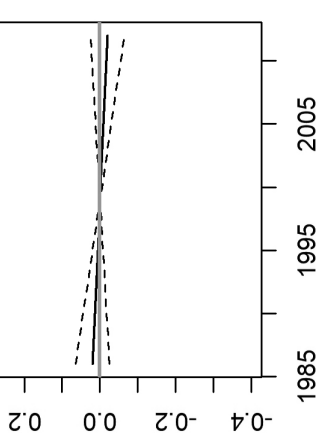

נeәu! 7 :s|enp!səd je!̣ued

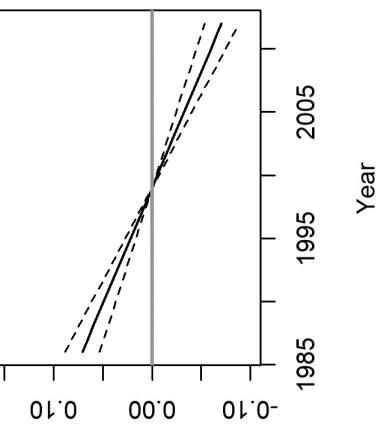

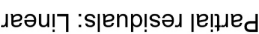




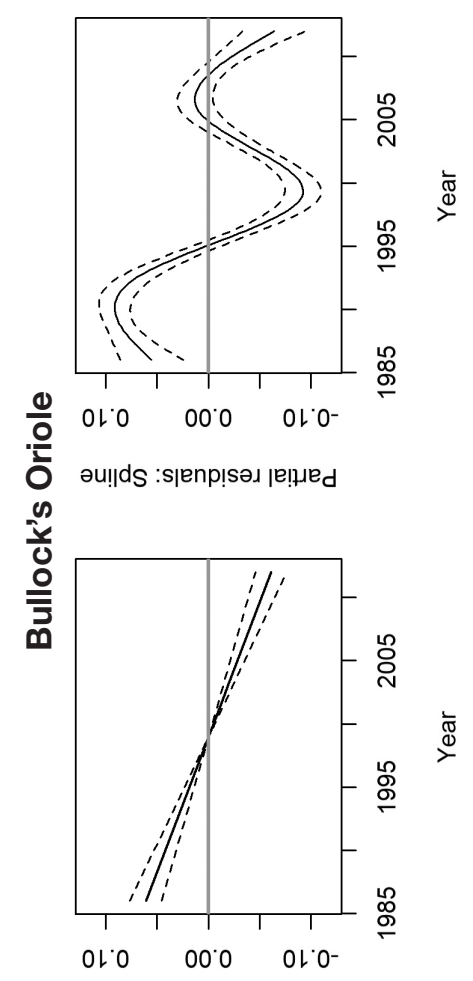

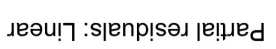

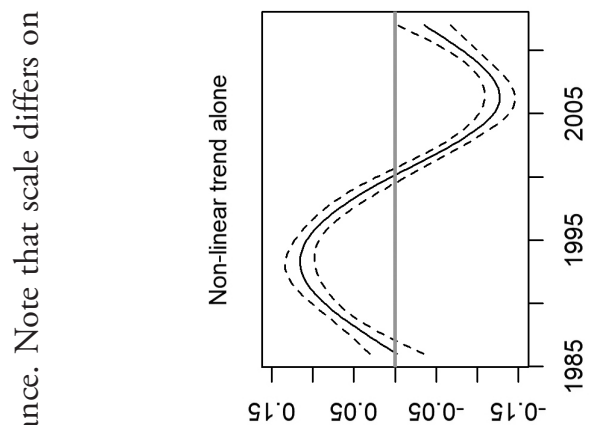

:

cั)

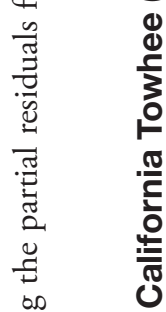

.

$\stackrel{\mathbb{2}}{\Xi}$

ఫ苞

㟧:

范范

\&

荧

ㄴํํำ

苨

至先
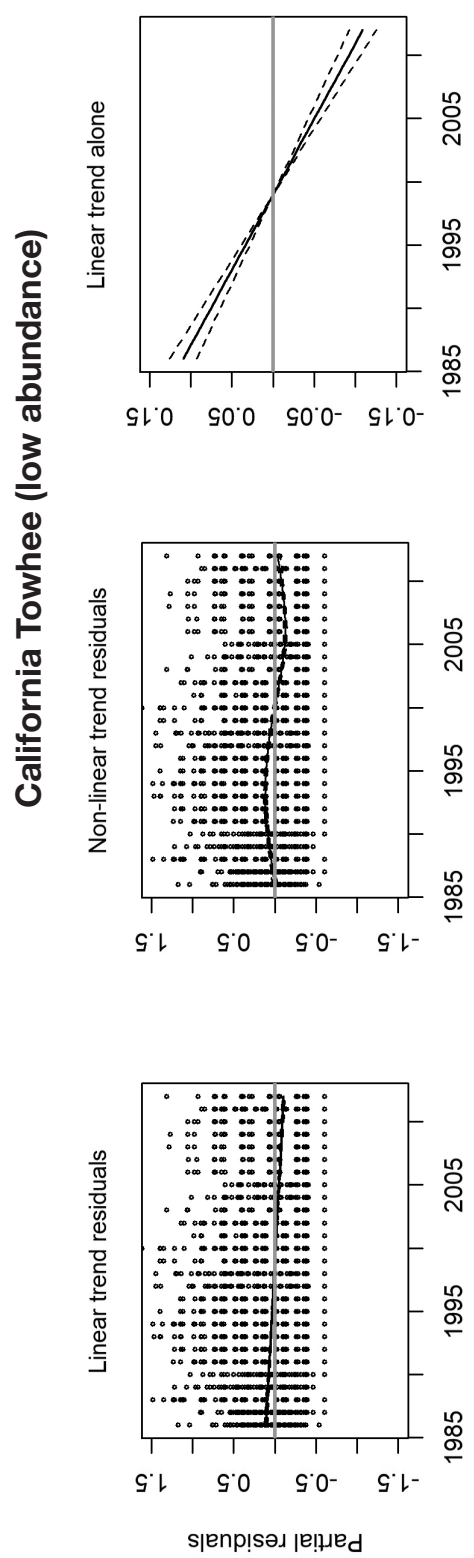

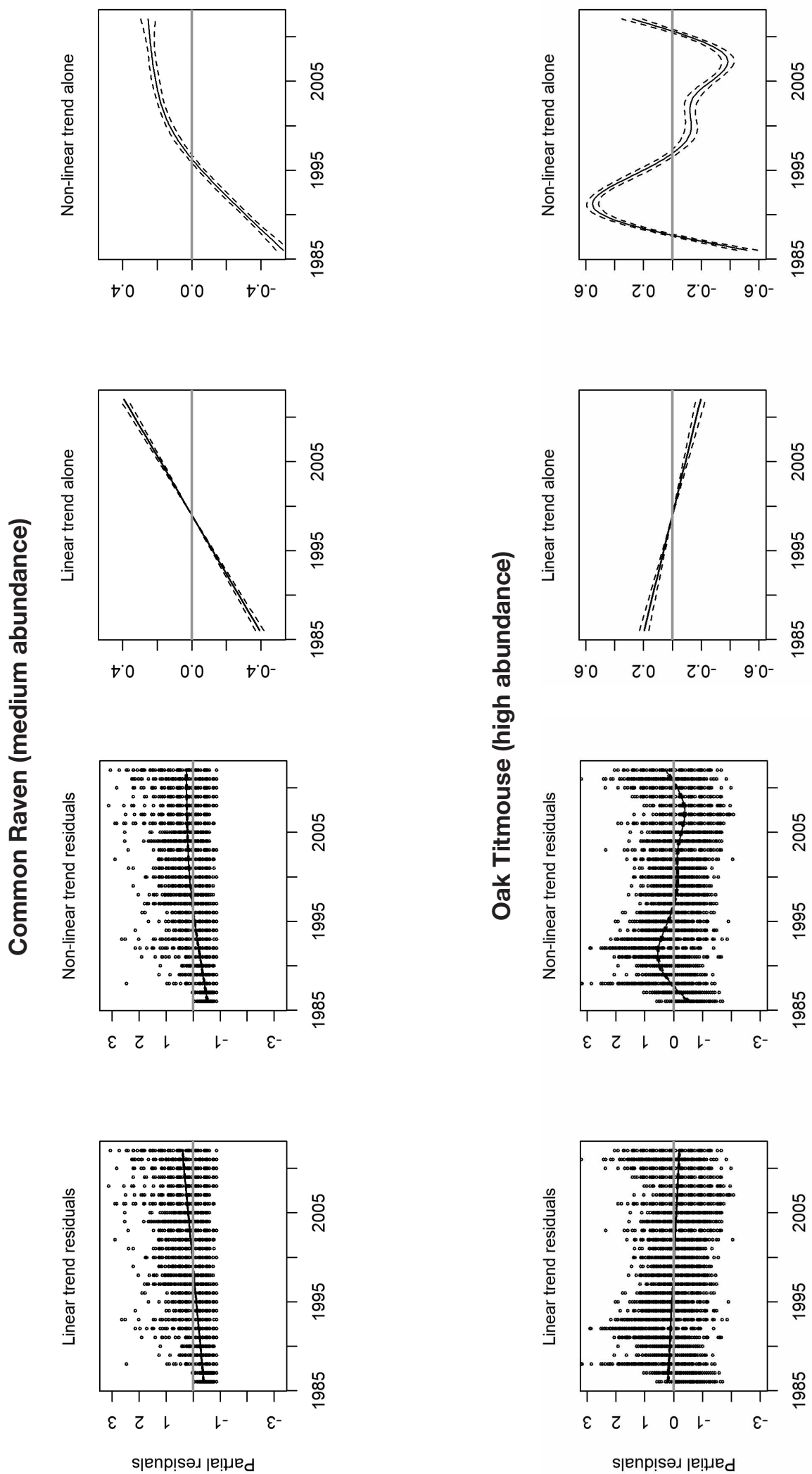